\title{
Review of Clupeotoxism, an Often Fatal Illness from the Consumption of Clupeoid Fishes ${ }^{1}$
}

\begin{abstract}
Fobn E. Randall ${ }^{2}$
Abstract: Poisoning from eating clupeoid fishes such as sardines and herrings (Clupeidae) or anchovies (Engaulidae), termed clupeotoxism, is widespread in tropical and subtropical areas of the world but rare. A fatal case occurred in Kaua' $i$ in 1978 from the consumption of the Marquesan Sardine (Sardinella marquesensis). This species has been replaced in abundance in the Hawaiian Islands by another import, the Goldspot Sardine (Herklotsichthys quadrimaculatus). Onuma et al. (1999) obtained the head of a specimen of this sardine that caused a fatality in Madagascar and found that it contained palytoxin. Because bottom sediment was detected on the gills and in the esophagus, they concluded that the fish is a bottom-feeder, and the benthic dinoflagellate Ostreopsis siamensis, known to produce palytoxin, the toxic organism. The sediment on the gills was more likely the result of the fish being dragged over the substratum by a seine. The Goldspot Sardine feeds on zooplankton, not benthic organisms. Therefore, a pelagic dinoflagellate is the probable producer of palytoxin.
\end{abstract}

The consumption of certain tropical marine fishes, even though well cooked, may result in severe illness and even death. Halstead and Lively (1954) separated such poisonings into four groups, ciguatera, tetraodon poisoning, gymnothorax (moray eel) poisoning, and scombroid (tuna) poisoning. In a review of ciguatera, Randall (1958) pointed out that gymnothorax poisoning is severe ciguatera, and scombroid poisoning is usually food poisoning (unrefrigerated tunas and bonitos spoil quickly by bacterial action). He briefly mentioned other valid categories of toxemia from eating fishes, including one resulting from ingestion of "certain tropical clupeid fishes," later called clupeoid poisoning or clupeotoxism.

Halstead (1967) reviewed cases of clupeotoxism, the first by Desportes (1770) from

\footnotetext{
${ }^{1}$ Manuscript accepted 7 April 2004.

2 Bishop Museum, 1525 Bernice Street, Honolulu, Hawai'i 96817-2704 (e-mail: jackr@hawaii.rr.com).
}

Pacific Science (2005), vol. 59, no. 1:73-77

(C) 2005 by University of Hawai'i Press

All rights reserved eating a sardinelike fish known as Clupea thryssa (= the thread herring Opisthonems oglinum) at what is now the Dominican Republic. Oldendorp (1777) claimed that sprat (a general English common name for a clupeid) is the most poisonous fish in the Virgin Islands, adding that it is toxic only in circumscribed areas and at certain times of the year. Halstead (1967:610) listed 87 references dealing with clupeoid poisoning. He concluded with the following statement, "It is noteworthy that to date no one has reported any experimental work on the toxicology, pharmacology, or chemistry of these violently poisonous fishes. Apparently clupeiform fishes, which are generally valuable food fishes, become toxic only at sporadic intervals. The biotoxicity of these fishes appears to be a completely unpredictable phenomenon."

Halstead (1978:492) gave the symptoms of clupeoid poisoning as follows: "The first indication of a biotoxication is the sharp metallic taste which may be present immediately upon ingestion of the fish. This is soon followed by nausea, dryness of the mouth, vomiting, malaise, abdominal pain, and diarrhea. The gastro-intestinal upset may be accompanied by a feeble pulse, tachycardia, chills, cold clammy skin, vertigo, a drop in blood 
pressure, cyanosis and other evidences of vascular collapse. Within a very short period of time, or concurrently, a variety of neurological disturbances rapidly ensue such as nervousness, dilated pupils, violent headaches, numbness, tingling, hypersalivation, muscular cramps, respiratory distress, progressive muscular paralysis, convulsions, coma and death. Death may occur in less than 15 minutes. Fergusen (1823) claimed that the poison was so rapid in its action that natives have died while in the very act of eating the yellow-billed sprat...."

Melton et al. (1984) reported on the death of a fisherman on Kaua' $i$ from eating three Marquesan Sardines (Sardinella marquesensis) in 1978. I (second author of the paper) identified the fish from skeletal remains obtained from the family of the deceased. This species was introduced to $\mathrm{O}^{\prime}$ ahu from Nuku Hiva, Marquesas, as a tuna baitfish between 1955 and 1959 during seven cruises of the research vessel Hugh M. Smith. In late 1958 small individuals were found, indicating that the species had become established. The sardine never became abundant enough to be of value as a baitfish, and it has not been reported in recent years.

A second sardine, the Goldspot Sardine (Herklotsichtbys quadrimaculatus), was first noticed in Kāne'ohe Bay, O'ahu, in 1975, becoming abundant in the bay the following year. Figure 1 illustrates a specimen from American Samoa. Williams and Clarke (1983) reported on its biology in $\mathrm{O}^{\prime}$ ahu, admitting that they first thought it was the Marquesan Sardine. The Goldspot Sardine may have entered Hawaiian waters in 1972 when the tuna-fishing vessel Anela dumped baitfish identified only as sardines on the return cruise from Jaluit, Marshall Islands, where the bait had been seined (Randall 1987). The

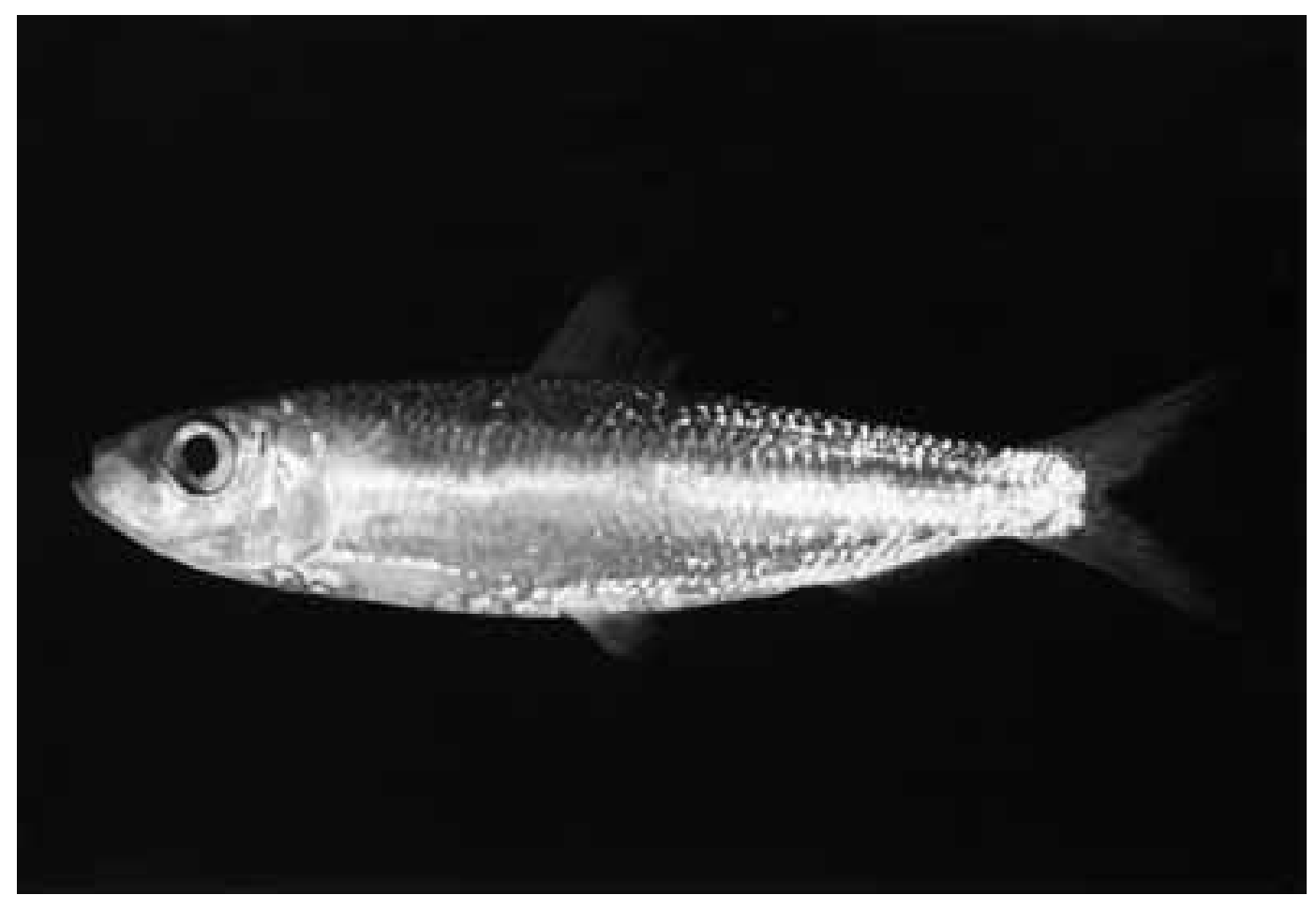

Figure 1. Goldspot Sardine (Herklotsichthys quadrimaculatus), Tutuila, American Samoa. 
poisonous sardine in Kaua' $i$ was probably not H. quadrimaculatus, because a sample of eight fish caught soon after the poisoning was identified as Sardinella marquesensis, and $H$. quadrimaculatus was not yet known from the island.

Melton et al. (1984:119) wrote, "Sardines, herrings, and anchovies feed on planktonic organisms, thus the source of the toxin is not benthic as it is in ciguatera. The toxic fishes are often caught in turbid, brackish areas in contrast to the clear-water, coral-reef habitat typical of ciguatera. These clupeoid fishes are the first to acquire the toxin, whereas those producing ciguatera in its most severe form are the large carnivorous species at the upper end of the food chain. The size of the fish causing clupeoid poisoning does not seem to be related to the intensity of the toxemia, in sharp contract to the fishes that cause ciguatera. Also significant in this fatality is the frequent observation that victims who were the most ill or died were ones who had eaten viscera as well as the flesh of the fish." They then gave evidence of this from outbreaks in Fiji, Tonga (Banner and Helfrich 1964) and Jamaica. They also noted that clupeoid poisoning takes place during the warm months of the year, in contrast to ciguatera, which may occur at any season.

Melton et al. (1984:120) stated, "The probable source of clupeotoxin is a planktonic dinoflagellate. The first suggestion of this was made by D'Arras in 1877, according to Halstead (1967), who reported the observation of Father Montrouzier in New Caledonia that local sardines become poisonous because they feed on a 'green monad' which discolored areas of the sea seasonally at the region of Balade. These monads cause conjunctivitis, coryza and erythema in persons coming in contact with them."

The seasonality of clupeoid poisoning may be related to the generally heavier rainfall during summer months in tropical and subtropical localities. The World Health Organization report (1980:259) of the outbreak in Jamaica on 4-5 July 1979 stated, "It is interesting to note that one of the most severe floodings in over a century occurred on 12 June in the involved part of the island. The previous incident of sprat poisoning in May was also preceded by flood weather in March." The Kaua'i poisoning by the Marquesan Sardine on 3 October followed a period of heavy rain.

Paralytic shellfish poisoning (PSP), which has resulted from eating mussels and other bivalve mollusks during the warm months in temperate waters, has been attributed to planktonic dinoflagellates of the genus $\mathrm{Go}_{0}$ nyaulax. The symptomatology of PSP, however, is clearly different from that of clupeoid poisoning. Nevertheless, another pelagic dinoflagellate of tropical and subtropical seas should be expected as the responsible organism for the poisoning from eating clupeoid fishes.

It is surprising that Onuma et al. (1999) concluded that the benthic dinoflagellate Ostreopsis siamensis is the cause of clupeotoxism. On 9 January 1994 in the Antalaha District of Madagascar, a woman of age 49 obtained four sardines that were identified as Herklotsichthys quadrimaculatus. She cut off the head of two of the fish, cooked the body parts, and fed one to herself and one to her child. She noticed an unusual bitter taste of the fish. A cat that had eaten the remains of the fish died in $15 \mathrm{~min}$. The woman became seriously ill and was taken to the hospital where she died $15 \mathrm{hr}$ after eating the sardine. The child did not show any sign of poisoning. The head of the toxic fish and that of the nontoxic one were retrieved from the kitchen, frozen, and later placed in ethanol before being sent to the authors. Their analysis resulted in the identification of the causative agent as palytoxin, first isolated from the benthic colonial coelenterate Palythoa in Maui by Moore and Scheuer (1971). Its structure was defined by Moore and Bartolini (1981) and Uemura et al. (1981), and its pharmacology by Hirata et al. (1988).

Part of the esophagus of one of the sardines was attached to the head. Microscopic examination of the gills and esophagus revealed a large amount of bottom sediment. Because of this, Onuma et al. (1999:64) wrote, "It is highly likely therefore that the fish obtain the toxin from a benthic organism. In view of the fact that Ostreopsis spp. densely 
grow on the bottom in tropical seas (Faust, 1995) and produce palytoxin and its analogs, most probably the dinoflagellate is the source of the toxin in the sardine." They added that Alcala et al. (1988) reported a human fatality from ingesting the crab Demania reynaudii in the Philippines that was shown to contain a palytoxin-like toxin.

There is another explanation for the presence of bottom sediment in the gills and the esophagus of the two sardines from Madagascar. This schooling species occurs inshore in protected waters and is generally taken by seines or throw nets. When the fish are dragged over the bottom, the gills and esophagus may become heavily laden with sediment. Williams and Clarke (1983) reported the usual depth of Herklotsichthys quadrimaculatus during the day over reef flats of Kāne'ohe Bay, O'ahu, as 1-2 m. At night the fish disperse from the shallows for their primary feeding. Their food consists of a wide variety of zooplankton, the smaller fish eating mainly small copepods. There was no evidence of feeding on phytoplankton, but of course copepods and other small zooplanktonic animals are responsible for that major source of nutrition entering the food chain in the sea. A bottom-dwelling crab could obtain palytoxin by eating filter-feeding benthic invertebrates in its community.

Melton et al. (1984:120) wrote, "The people of Hawaii do not often eat local clupeoid fishes, and when they do, they are apt to eviscerate them. Thus, the potential for outbreaks in Hawaii may be lower than in less developed insular regions of the world." They concluded, "We also believe there is ample reason to inform the public of the hazards associated with the consumption of clupeoid fishes in Hawaii."

Palytoxin used as a reference in the study by Onuma et al. (1999) was obtained from Wako Pure Chemical in Osaka, and antipalytoxin monoclonal antibody 73D3 (mAb73D3) from Hawaii Biotech, Honolulu. Onuma et al. (1999) recommended treating patients poisoned by palytoxin with vasodilatory agents such as papaverine or isosorbide dinitrate, as suggested by Vick and Wils (1990).

\section{Literature Cited}

Alcala, A. C., L. C. Alcala, J. S. Yasumura, and D. Yasumoto. 1988. Human fatality due to ingestion of the crab Demania reynaudii that contained a palytoxin-like toxin. Toxicon 26:105-107.

Banner, A. H., and P. Helfrich. 1964. The distribution of ciguatera in the tropical Pacific. Tech. Rep. Hawaii Mar. Lab. 3:148.

Desportes, J. B. 1770. Histoire des maladies de S. Domingue. Vol. 1: 108-110.

Halstead, B. W. 1967. Poisonous and venomous marine animals of the world. Vol. 2. Vertebrates. U.S. Government Printing Office, Washington, D.C.

- 1978. Poisonous and venomous marine animals of the world. Darwin Press, Princeton, New Jersey.

Halstead, B. W., and W. M. Lively. 1954. Poisonous fishes and ichthyoscarcotoxism. U.S. Armed Forces Med. J. 5 (2): 157-175.

Hirata, Y., D. Uemura, and Y. Ohizumi. 1988. Chemistry and pharmacology of palytoxin. Pages 241-258 in Handbook of natural toxins. Vol. 3. Marine toxins and venoms. Marcel Dekker, New York.

Melton, R. J., J. E. Randall, N. Fusetani, R. S. Weiner, R. D. Couch, and J. K. Sims. 1984. Fatal sardine poisoning. Hawaii Med. J. 43 (4): 114-120, 124.

Moore, R. E., and G. J. Bartolini. 1981. Structure of palytoxin. J. Am. Chem. Soc. 103:2491-2494.

Moore, R. E., and P. J. Scheuer. 1971. Palytoxin: A new marine toxin from a coelenterate. Science (Washington, D.C.) 172:495-498.

Oldendorp, C. G. 1777. Geschichte der mission der evangelischen brüder auf den caraibischen inseln St. Thomas, St. Croix, und St. Jean. Vol. 2, no. 6: 110-111.

Onuma, Y., M. Stake, T. Ukena, J. Roux, S. Chanteau, N. Rasolofornirina, M. Ratsimaloto, H. Naoki, and T. Yasumoto. 1999. Identification of putative palytoxin as the cause of clupeotoxism. Toxicon 37:5565.

Randall, J. E. 1958. A review of ciguatera, tropical fish poisoning, with a tentative 
explanation of its cause. Bull. Mar. Sci. Gulf Caribb. 8 (3): 236-267. 1987. Introductions of marine fishes to the Hawaiian Islands. Bull. Mar. Sci. 41 (2): 490-502.

Uemura, D., K. Ueda, and Y. Hirata. 1981. Further studies on palytoxin II structure of palytoxin. Tetrahedron Lett. 22:27812784.

Vick, J. A., and J. Wils. 1990. Pharmacological and toxicological studies of paly- toxin. ACS (Am. Chem. Soc.) Symp. Ser. 418:241-254.

Williams, V. R., and T. A. Clarke. 1983. Reproduction, growth, and other aspects of the biology of the gold spot herring, Herklotsichthys quadrimaculatus (Clupeidae), a recent introduction to Hawaii. Fish. Bull. 81 (3): 587-597.

World Health Organization. 1980. Fish poisoning. WHO Weekly Epidemiol. Rec. $55: 258-259$. 
